\title{
Main Phases of Wood Formation in Chestnut (Castanea sativa) in Central Italy - Comparison of Seasons 2008 and 2009
}

\section{Glavne faze razvoja drva pitomog kestena (Castanea sativa) u središnjoj Italiji - usporedba sezone 2008 i 2009}

\author{
Original scientific paper • Izvorni znanstveni rad \\ Received-prispjelo: 21. 7. 2011. \\ Accepted-prihvaćeno: 22. 11.2011. \\ UDK: $630 * 811.1 ; 674.031 .632 .254 .2$ \\ doi:10.5552/drind.2011.1124
}

\begin{abstract}
We present wood formation in chestnut (Castanea sativa) during the growing seasons 2008 and 2009, compare its dynamics in the two years and discuss possible effects on wood quality. To this purpose, microcores containing wood, cambium and phloem were collected at weekly intervals from 10 chestnut trees growing at the Cimini mountains near Viterbo, Central Italy. In 2008, the onset of wood formation started before the first sampling on 17 April 2008. Onset of lignification of the first formed vessels was observed around 23 April (day of the year DOY 113.8 \pm 5.3 ) and the first latewood vessels were observed around 5 June 2008 (DOY 156.5 \pm 7.7$)$. Latewood formation continued until 29 September 2008 (DOY 273.9 \pm 10.5 ) when the terminal cells of the newly formed xylem ring were fully lignified. In 2009, the main phases of wood formation generally occurred earlier than in 2008. The expansion of earlywood vessels was observed around 10 April (DOY $99.7 \pm 6.1$ ), the onset of

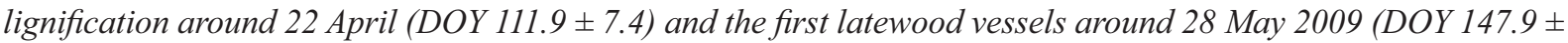
4.7). Lignification of the last formed cells was completed by 26 September 2009 (DOY 273.9 \pm 10.5 ). The average duration of tree-ring formation was 161 days in 2008 and 169 days in 2009, the average ring widths were $3296 \pm$ $1514 \mu \mathrm{m}$ in 2008 and $3166 \pm 1073 \mu \mathrm{m}$ in 2009, and latewood percentages comprised $76 \%$ and $74 \%$ of the 2008 and 2009 tree-rings, respectively. The small differences in timing of wood formation phases in the two study years are probably due to small variations in climatic conditions between the two years and they did not seem to have a major impact on ring widths and latewood percentages, which are two important parameters affecting wood quality in ring porous wood species.
\end{abstract}

Key words: Castanea sativa, sweet chestnut, Central Italy, wood formation, wood quality

SAŽETAK • Rad obrađuje stvaranje drva pitomog kestena (Castanea sativa) tijekom vegetacije u 2008. i 2009. godini. Uspoređuje se dinamika stvaranja drva u te dvije godine i raspravlja o mogućem utjecaju na njegovu

\footnotetext{
Authors are associate professor, master of science and Ph.D., respectively, at Tuscia University, Viterbo, Italy. ${ }^{2}$ Authors are young researcher - Ph.D. student and professor, respectively, at University of Ljubljana, Biotechnical Faculty, Slovenia. ${ }^{3}$ Author is assistant professor and senior research associate at Slovenian Forestry Institute, Ljubljana, Slovenia.

Autori su redom, izvanredna profesorica, magistrica i doktor, Sveučilište Tuscia, Viterbo, Italija. ${ }^{2}$ Autori su, redom, znanstveni novak - doktorand i redovna profesorica, Sveučilište u Ljubljani, Biotehnički fakultet, Slovenija. ${ }^{3}$ Autorica je docentica i viša znanstvena suradnica, Slovenski šumarski institut, Ljubljana, Slovenija.
} 
kvalitetu. Za tu su svrhu s deset stabala pitomog kestena u planinama Cimini, pokraj mjesta Viterbo u središnjoj Italiji, u tjednim intervalima skupljeni mikroizvrtci koji su sadržavali drvo, kambij i floem. Početak stvaranja drva u 2008. godini dogodio se prije uzimanja prvih uzoraka 17. travnja 2008. Početak lignifikacije prvooblikovanih traheja primijećen je oko 23. travnja (dan u godini DOY 113,8 $\pm 5,3$ ), a prve traheje kasnog drva primijećene su oko 5. lipnja (DOY 156,5 \pm 7,7). Stvaranje kasnog drva nastavljeno je do 29. rujna 2008. (DOY 273,9 $\pm 10,5$ ), kad su završne stanice novostvorenoga goda drva bile potpuno lignificirane. U 2009. godini glavne su se faze stvaranja drva uglavnom pojavile ranije nego u 2008. godini. Širenje traheja ranog drva primijećeno je oko 10. travnja (DOY 99,7 $\pm 6,1$ ), početak lignifikacije oko 22. travnja (DOY 111,9 \pm 7,4), a prve traheje kasnog drva oko 28. svibnja 2009. (DOY 147,9 \pm 4,7). Lignifikacija zadnjih proizvedenih stanica završena je do 26. rujna 2009. (DOY 273,9 \pm 10,5). Prosječno trajanje stvaranja goda drva u 2008. godini iznosilo je 161 dan, a u 2009. godini

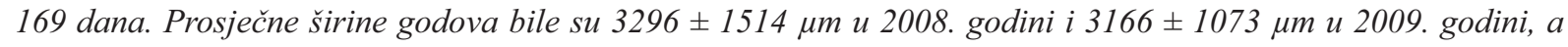
postotni udjel kasnog drva iznosio je 76 i 74\% godova u 2008., odnosno u 2009. godini. Male razlike u vremenu početka pojedine faza stvaranja drva u dvjema promatranim godinama vjerojatno su posljedica malih varijacija klimatskih uvjeta između te dvije godine i čini se da nemaju velik utjecaj na širinu godova ni na postotak kasnog drva, a to su dva važna čimbenika koji utječu na kvalitetu drva prstenasto poroznih vrsta.

Ključne riječi: Castanea sativa, pitomi kesten, središnja Italija, stvaranje drva, kvaliteta drva

\section{INTRODUCTION}

\section{UVOD}

Sweet chestnut (Castanea sativa Mill.) is the only native species of the genus Castanea in Europe and its cultivation has a long tradition. Chestnut is valued for its wood, bark and fruit. COST action G4 "Multidisciplinary Chestnut Research" based on National Forest Inventories reported in 1997 that 2.25 million hectares of forests in Europe were dominated by chestnut, with roughly $80 \%$ cultivated for wood and $20 \%$ for fruit production. Furthermore, three types of chestnut countries have been distinguished: (i) countries with a strong chestnut tradition (e.g. Italy, France, southern Switzerland, Spain, Portugal and Greece), where the chestnut stands are cultivated with intensive and characteristic silvicultural systems (coppices and orchards); (ii) countries with only a partially developed chestnut tradition due to the country's particular geography (e.g. England) or history (e.g. Croatia, Turkey, Georgia); and (iii) countries where the chestnut only sporadically occurs (e.g. Hungary, Bulgaria, Belgium) or has been recently introduced (e.g. Slovakia, Netherlands) (Conedera et al, 2004).

Sweet chestnut is a very common and important tree species in Italy. It grows all over the peninsula and is characteristic of the phytoclimatic association Castanetum, which grows in the altitudinal belt from 0 to $900 \mathrm{~m}$ a.s.l. in the north, and from 600 to $1200 \mathrm{~m}$ a.s.l. in the central and southern parts of Italy. The cultivation and use of chestnut fruit and wood has a long tradition all over Central Italy and also in the Province of Viterbo (Romagnoli et al, 2005; Romagnoli, 2007).

In this region, chestnut wood has been used in modern and in many historical buildings (Romagnoli et al, 2004; Romagnoli et al, 2005). The species is currently cultivated for wood production using coppice silvicultural management, in which new trees (shoots) grow from the stumps. The rotation time at least 14 years.

Chestnut belongs to ring-porous hardwoods with a morphological structure similar to oak wood (Schweingruber, 1990; Nardi Berti, 2006). Ring shakes are the main wood defect, which reduces the use of chestnut wood for high-added-value products. They are considered to occur as a consequence of growth stresses (radial tensile stress) and structural weakness of portions of wood tissue (Fonti and Macchioni, 2003; Spina and Romagnoli, 2010).

Since wood quality depends on wood structure, which is defined during the process of wood formation, a detailed knowledge of wood formation processes will improve our understanding of the relationship among wood structure and properties and the end-use of wood.

We started wood formation studies in chestnut in Central Italy in 2008 and the first results on cambial activity, wood and phloem formation in five trees in 2008 have already been published (Čufar et al, 2011). Since considerable tree to tree and year to year variability are expected, we evaluated the results of additional five trees sampled in 2008 and continued with the experiment in 2009.

The aim of the present study was to compare the seasonal dynamics of wood formation in ten trees in 2008 and 2009 and to discuss the effect of wood formation dynamics on wood quality.

\section{MATERIALS AND METHODS 2. MATERIJALI I METODE}

The study was carried out at a coppice chestnut (Castanea sativa Mill.) forest stand in the locality of the Cimini mountains, part of Comune di Soriano nel Cimino, Viterbo, Italy (approx. $42^{\circ} 17^{\prime} \mathrm{N}, 12^{\circ} 12^{\prime} \mathrm{E}, 850 \mathrm{~m}$ a. s.1.). The area is on volcanic soil, very close to the old beech forest described by Piovesan et al (2008). The climate is Mediterranean. The amount of annual precipitation in nearby Soriano nel Cimino is $1180 \mathrm{~mm}$ (Servizio Idrografico, 1916-2000). The precipitation maximum is recorded from October until December and the driest period occurs in summer, although there is no significant evidence of drought according to the Bagnouls-Gaussen diagram (Piovesan et al, 2008). The mean annual temperature is $14{ }^{\circ} \mathrm{C}$, with a maximum in August (up to $24.2^{\circ} \mathrm{C}$ ) and minimum in December $\left(6.2^{\circ} \mathrm{C}\right)$ (Servizio idrografico 1997-2001). The daily data (minimum and 


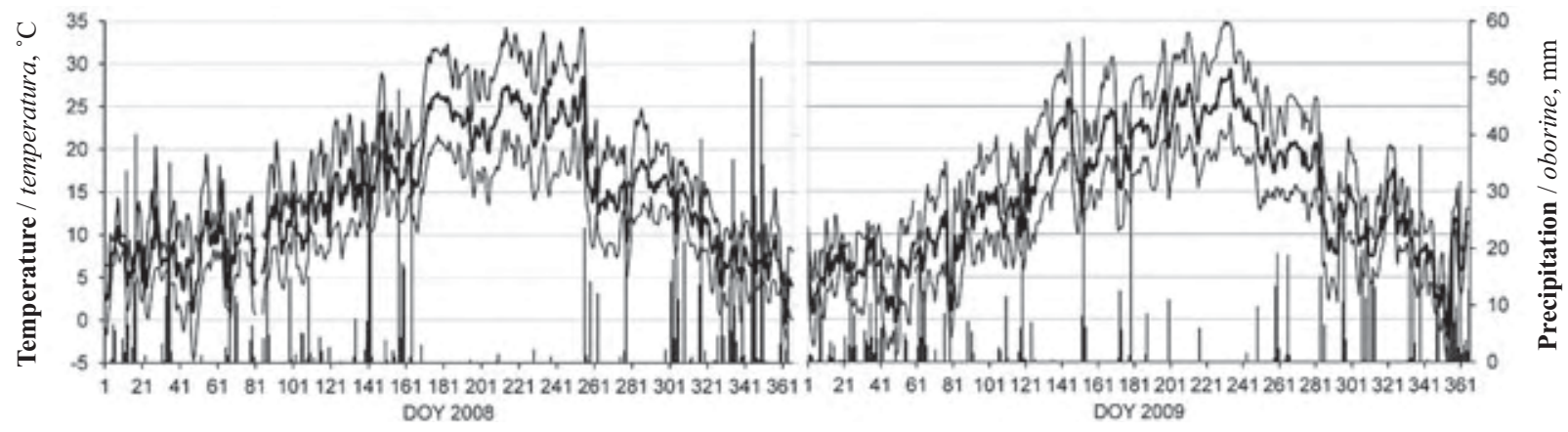

Figure 1 Daily climatic data, minimum, mean and maximum temperatures (lines), and precipitation (bars), for Soriano nel Cimino, Central Italy, in 2008 and 2009.

Slika 1 Dnevni klimatski podatci u 2008. i 2009. za Soriano nel Cimino, središnja Italija: minimalne, prosječne i maksimalne temperature (krivulje) i oborine (trake)

maximum temperature and precipitation) for 2008 and 2009 are presented in Fig. 1.

We selected ten isolated dominant healthy chestnut trees with approximate diameters of $17 \mathrm{~cm}$, heights of $15 \mathrm{~m}$, and ages of 30 years. The trees originate from stumps and ring shake defect was observed in some of them. Each tree represents a single shoot that had been left after cutting all other trees sprouting from the same stump, at the end of the rotation time in 2006. The sampling trees are now the standards of the site.

Samples of tissues containing the bark, cambium and the last formed wood were collected by taking micro-cores with Trephor (Rossi et al, 2006). The microcores (diameter $1.8 \mathrm{~mm}$, length approx. $15 \mathrm{~mm}$ ) were extracted from living trees, at the basal part of the stems, at weekly intervals from April until October 2008 and 2009.

Immediately after extraction from the tree, the samples were put in $70 \%$ ethanol for fixation and conservation. After the end of sampling, they were embedded in paraffin using a Leica TP 1020-1 tissue processor for dehydration in a graded series of ethanol $(70 \%$, $90 \%, 95 \%$ and $100 \%$ ) and bio-clear (D-limonene) for paraffin infiltration (Rossi et al, 2006). Cross-sections of $10 \mu \mathrm{m}$ thickness were prepared on a Leica RM 2245 rotary microtome, using disposable Feather N35H blades. For better adhesion of the sections, slides were pre-treated with albumin. Sections were dried at $70{ }^{\circ} \mathrm{C}$ for half an hour and cleaned of residual paraffin by immersing the slides in bio-clear and ethanol. Sections were finally stained for light microscopy with a mixture of safranin and astra blue ( $40 \mathrm{mg}$ safranin and 150 $\mathrm{mg}$ astrablue added to a solution of $100 \mathrm{ml}$ demineralized water with $2 \mathrm{ml}$ acetic acid) (van der Werf et al, 2007) and mounted on glass slides in Euparal.

A Nikon Eclipse 800 light microscope (bright field and polarized light), Nikon digital sight DS-Fi1 video camera and the NIS elements BR 3.0 image analysis system were used for observations and semi-automatic counting and measuring of cells and tissues at various stages of their development. We also measured the width of the current increment as well as early- and latewood widths (in $\mu \mathrm{m}$ ). The measurements were always done in each sample along three radial files. The boundary between earlywood and latewood was defined based on vessel dimensions; vessels smaller than
$10,000 \mu \mathrm{m}^{2}$ were considered to belong to latewood (Fonti et al, 2007).

In the newly formed wood tissue, we could follow the development of the vessels, vasicentric tracheids around them (referred to in brief as tracheids) and tracheids or fibres apart from the vessels (fibres) (Figs. 2, 3). We recorded the following phases of cell development: post-cambial growth (PC), secondary cell wall deposition and lignification (SW) and mature cells (MT) (Fig. 3). The PC cells contained thin, nonlignified cell walls that stained blue with astra blue

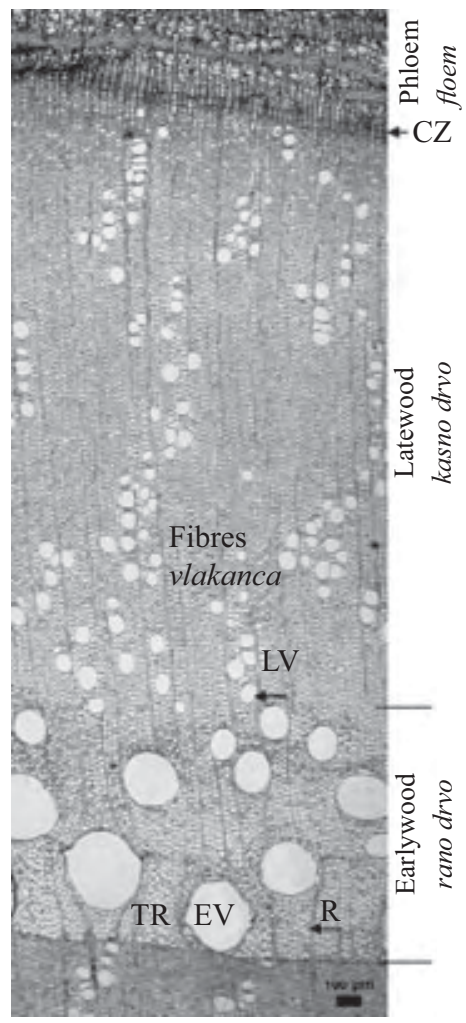

Figure 2 Cross-section of Castanea sativa tissues showing the last formed xylem ring divided into earlywood and latewood, cambial zone (CZ) and phloem. The cells of the wood are: earlywood vessels (EV), latewood vessels (LV), tracheids (TR) and fibres. The rays (R) are uniseriate. Slika 2. Poprečni presjek zadnjih proizvedenih tkiva Castanea sativa s ranim i kasnim drvom, kambijskom zonom (CZ) i floemom. Stanice drva su traheje ranog drva (EV), traheje kasnog drva (LV), traheide (TR) i vlakanca. Traci (R) jednoredni su. 
stain (Fig. 3 a) and showed no birefringence under polarized light (Fig. 3 b). In this phase, the cells enlarged in radial and tangential directions (vessels) or elongated (tracheids, fibres). The beginning of the secondary wall deposition was detected under polarized light, since the cell walls showed birefringence (Fig. 3 b). The beginning of cell wall lignification could be observed under bright-field, when red stain safranin gradually replaced the blue staining (Fig. 3 a).

\section{RESULTS AND DISCUSSION}

\section{REZULTATI I DISKUSIJA}

In 2008, the onset of cambial divisions and the first earlywood vessels in the phase of expansion occurred before our first sampling on 17 April (Čufar et al, 2011). In 2009, the first earlywood vessels in the phase of expansion were observed around 10 April (day of the year DOY $99.7 \pm 6.1$ ) (Fig. 4), while the onset of cambial cell production was recorded on 2 April 2009 (DOY $92.0 \pm 6.4$ ).

Previous reports on wood formation in chestnut are extremely rare. In the 1940s, Ciampi (1951) sampled two chestnut trees at two sites in Tuscany in Italy: near San Giusto, at $500 \mathrm{~m}$ a.s.1. in the 1947 growing season, and near Vallombrosa at $1000 \mathrm{~m}$ a.s.1. in the 1949 growing season. It was observed that the onset of cambial activity and earlywood production differed between the two localities. In San Giusto, earlywood vessels were already formed at the beginning of April and lignification of the initial vessels was concluded by mid-May. In Vallombrosa, the onset of cambial activity occurred much later; at the end of April, but lignification was already evident at the beginning of May.

Since other reports on wood formation in chestnut are not available, we can compare our observations with those in other ring porous species, which have been conducted in various geographic areas. Gričar (2010) followed wood formation in Quercus petraea (sessile oak) in Ljubljana, Slovenia, at $323 \mathrm{~m}$ a.s.1. in 2007 and observed that the first earlywood vessels were created by mid-April. Horaček et al. (2003) presented xylem formation in Quercus robur (pedunculate oak) in Czech Republic. They observed that the activity of cambium started before the first sampling on 27 April 1998, when on average 6.66 radially enlarging cells were already observed. A study by Derr and Evert (1967) on young Robinia pseudoacacia (black locust) trees in Madison, USA, from October 1960 until October 1962, reported that the first signs of cambial cell divisions were observed on 18 April 1961 and on 7 April 1962. The first expanding vessels were observed on 27 April 1962.

Sass-Klaassen et al. (2011) studied vessel formation in Quercus robur and Fraxinus excelsior (pedunculate oak and ash) in relation to leaf phenology in 2008 in the Netherlands $\left(52^{\circ} 23^{\prime} \mathrm{N}, 5^{\circ} 37^{\prime} \mathrm{E}\right)$. Vessel formation in ash started well before bud swelling and much earlier than in oak. Earlywood vessel formation in oak on average already started at the end of March and ended at the beginning of May. In ash, vessel for- mation started 13 days earlier than in oaks and ended around the beginning of May.

It is generally known that the first earlywood vessels develop before bud break in ring-porous trees such as Castanea, Quercus, Fraxinus and Robinia, and therefore before the resumption of photosynthetic activity. Formation of the first earlywood vessels can occur two to six weeks prior to bud break (Suzuki et al, 1996; Schmitt et al, 2000; Sass-Klaassen et al. 2011). The early phases of earlywood formation thus require the mobilization of reserves stored during the previous growing season (Barbaroux and Bréda, 2002).

Fonti et al. (2007) tried to identify the climatic signals contained in the earlywood vessel size of Castanea sativa from Valle Mesolcina $\left(46^{\circ} 14^{\prime} \mathrm{N}, 9^{\circ} 07^{\prime} \mathrm{E}\right.$, elevations 300, 600 and $900 \mathrm{~m}$ a.s.1.) in Switzerland and the physiological processes involved in the underlying mechanisms. They reported that the first vessels appeared in late April to early May. They hypothesised that April temperatures are related to tree activation, whereby new hormone production fosters vessel expansion.

Deposition of the secondary wall layers and lignification of first formed vessels and surrounding fibres/fibre tracheids started at almost the same time, around 23 April 2008 (DOY $113.8 \pm 5.3$ ) and around 22 April 2009 (DOY 111.9 \pm 7.4) (Fig. 4). The onset of deposition was recognized due to birefringence of vessels and fibres observed under polarized light (Fig. 3b), whereas lignification was characterized by red staining of the cell walls observed in bright-field (Fig. 3a).

As reported by several studies, both secondary wall formation and lignification start first in the vessels and in the cells that are in contact with the vessels (Murakami et al, 1999; Terashima 2000; Grünwald et al, 2002; Marion et al, 2007; Prislan et al, 2009). Since
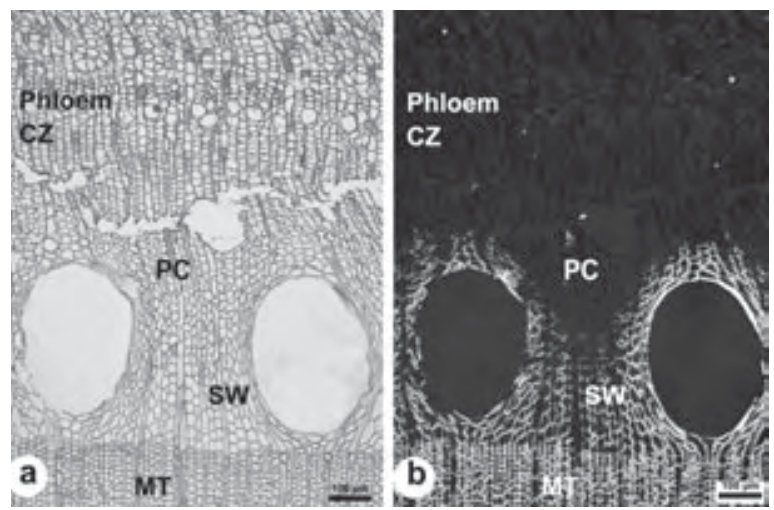

Figure 3 Cells in different phases of formation observed under a light microscope: (a) bright field and (b) polarized light. Phases of cell formation: post-cambial growth (PC), secondary cell wall deposition and lignification (SW) and mature cells (MT) formed in the season.

Slika 3. Stanice u različitim fazama razvoja promatrane svjetlosnim mikroskopom: (a) u svijetlom polju i (b) u polariziranoj svjetlosti. Faze razvoja stanica obuhvaćaju: postkambijski rast (PC), odlaganje sekundarnog sloja stijenke i lignifikacija (SW) te odrasle stanice (MT) proizvedene u sezoni. 


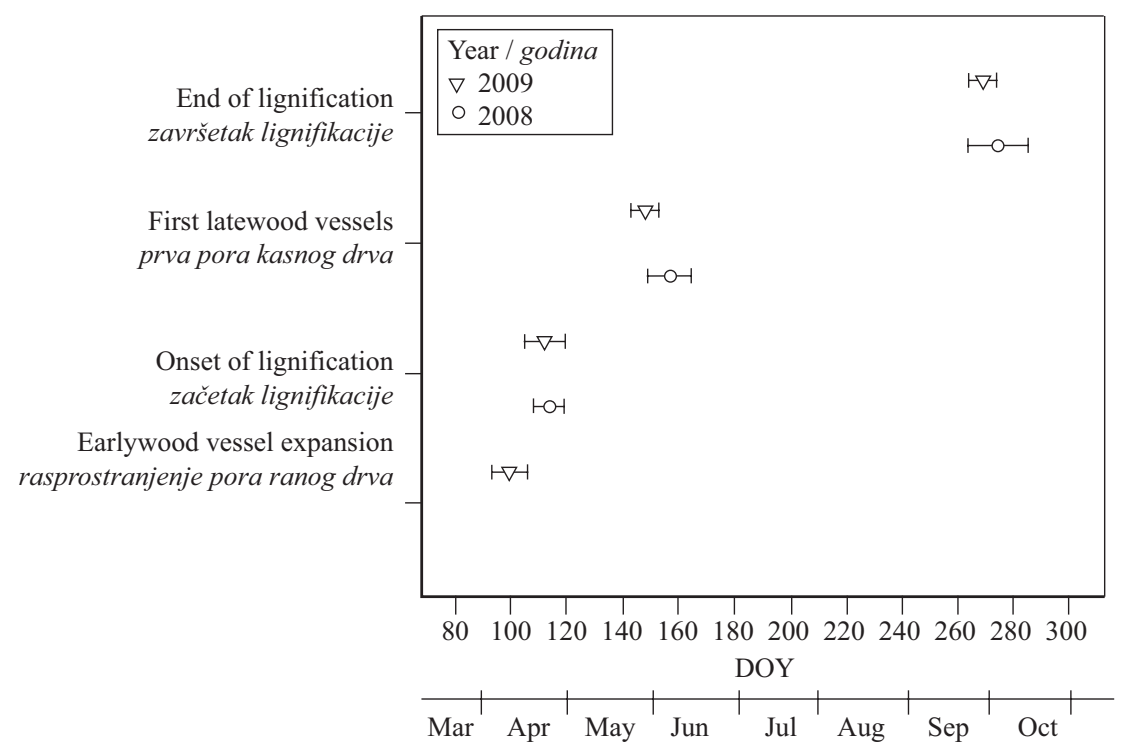

Figure 4 Milestones of wood formation in 2008 and 2009 shown for days of the year (DOY) and calendar dates, with variation ( \pm standard deviation).

Slika 4. Prekretnice u stvaranju drva u 2008. i 2009. godini prikazane za dane u godini (DOY) i kalendarske datume, s varijacijom ( \pm standardna devijacija)

ring-porous species mainly transport water through the wide early-wood vessels of the current growth ring (Suzuki et al, 1999), early establishment of water conducting pathways is particularly important (Sass, 1993).

Earlywood formation was completed and the first newly formed late-wood vessels were observed around 5 June (DOY 156.5 \pm 7.7 ) in 2008 and around 28 May (DOY $147.9 \pm 4.7$ ) in 2009 (Fig. 4).

Gričar (2010) observed a transition from early- to latewood in Quercus petraea slightly earlier; i.e., in the third week of May 2008. Derr and Evert (1967) observed that the period of greatest cambial activity coincided with earlywood formation in Robinia pseudoacacia. Furthermore, Schmittet al.(2000), who investigated wood production in Robinia pseudoacacia near Hamburg, Germany reported that wood formation started around 3 May, and about $70 \%$ of wood was already formed by 5 July.

Xylem growth ring formation in chestnut was completed when the last formed xylem cells were completely lignified. In both years, this was observed at approximately the same time, i.e., around 29 September 2008 (DOY $273.9 \pm 10.5$ ) and around 26 September 2009 (DOY $269.1 \pm 4.7$ ) (Fig. 4).

Ciampi (1951) observed that lignification of the terminal xylem cells in Castanea sativa concluded in October. Schmitt et al. (2000) noted the end of wood formation in Robinia pseudoacacia in the second week of September. Derr and Evert (1967) reported that cambial activity in Robinia pseudoacacia ended in early September; however, xylem differentiation did not end until October. Termination of cambial activity, when no wood increment was noticed, occurred from the end of September to October in Quercus robur in Czech Republic (Horaček et al, 2003).

According to the presented data the xylem growth ring formation in the studied chestnuts lasted on average $160.7 \pm 13.0$ days in 2008 and slightly more, 169.4 \pm 8.0 days, in 2009 . The duration slightly varied from tree to tree and the differences were larger in 2008 $(\mathrm{RSD}=10 \%)$ than in $2009(\mathrm{RSD}=4 \%)$.

The duration of earlywood formation was on average $43.9 \pm 8.9$ days in 2008 and $48.2 \pm 6.4$ days in 2009. The formation of latewood lasted on average $108.7 \pm 18.8$ days in 2008 and $110.7 \pm 7.9$ days in 2009 (Table 1). Early wood was thus formed in a period that lasted less than one third of the growing season.

Xylem ring in 2008 was on average $3296 \pm 1514$ $\mu \mathrm{m}$ wide and slightly narrower in 2009 , with $3166 \pm$ $1073 \mu \mathrm{m}$, although the growth season was about one week longer in 2009 (Table 1). Earlywood width on average comprised $702 \pm 430 \mu \mathrm{m}$ in 2008 and $781 \pm$ $209 \mu \mathrm{m}$ in 2009 and its proportion was similar in both years, with $24 \pm 11 \%$ in 2008 and $26 \pm 5 \%$ in 2009 . Consequently, the largest part of the xylem growth ring in both years consisted of latewood, the proportion of which was $76 \pm 12 \%$ in 2008 and $74 \pm 5 \%$ in 2009 (Table 1). The variation in earlywood proportion among

Table 1 Main characteristics of wood formation in 2008 and 2009

Tablica 1. Glavna obilježja stvaranja drva u 2008. i 2009.

\begin{tabular}{|l|c|c|}
\hline Measured parameter / Mjereni parametar & $\mathbf{2 0 0 8}$ & $\mathbf{2 0 0 9}$ \\
\hline Duration of wood formation, days / trajanje stvaranja drva, dani & $160.7 \pm 13.0$ & $169.4 \pm 8.0$ \\
\hline Duration of earlywood formation, days / trajanje stvaranja ranog drva, dani & $43.4 \pm 9.3$ & $48.2 \pm 6.4$ \\
\hline Duration of latewood formation, days / trajanje stvaranja kasnog drva, dani & $117.2 \pm 10.1$ & $121.2 \pm 5.0$ \\
\hline Total tree-ring width, $\mu \mathrm{m} /$ sirina cijeloga goda, $\mu \mathrm{m}$ & $3295.6 \pm 1513.6$ & $3166.1 \pm 1072.8$ \\
\hline Proportion of latewood, \% / udjel kasnog drva, \% & $75.7 \pm 11.2$ & $74.4 \pm 4.7$ \\
\hline
\end{tabular}


the trees was much higher in $2008(\mathrm{RSD}=46 \%)$ than in $2009(\mathrm{RSD}=18 \%)$.

We observed small differences in the timing of wood formation phases and duration of wood production between 2008 and 2009, and a comparable average width of tree-rings formed in the two years. The observed similarity in ring width and earlywood/latewood proportions are also expected to be reflected in a similar wood density.

The morphology of cells and the structure of the xylem growth ring are determined during wood formation. All this crucially affects wood properties. Chestnut is a typical representative of ring-porous wood species, with large earlywood vessels (mean diameters around $250 \mu \mathrm{m}$, range $150-300 \mu \mathrm{m}$ ), a more or less abrupt transition from early- to latewood, and small latewood vessels (mean diameters around $65 \mu \mathrm{m}$, range 36-125 $\mu \mathrm{m}$ ) (Wagenführ, 1996). The morphological cell structure of chestnut is comparable to that of oak (e.g., Quercus petraea and Quercus robur). Chestnut and oak can be differentiated on the basis of the size of rays, which are exclusively uniseriate in chestnut and of two sizes, uniseriate and over 10 cells wide ones, in oaks (Schweingruber, 1990; Nardi Berti, 2006). The oven-dry density of chestnut wood is $530-590 \mathrm{~kg} / \mathrm{m}^{3}$ (Wagenführ, 1996) and in ring porous wood species it mainly depends on the proportion of earlywood and latewood and increases with increasing ring width (Kollmann and Cote, 1968).

The observed differences in the wood formation dynamics in chestnut in 2008 and 2009 did not seem to have a major impact on wood quality as characterized by tree-ring widths and latewood percentages.

The climatic situation in the two years seemed to be similar (Fig. 1). However, to evaluate the effect of climate on wood formation and quality, we would need to explore in detail the climate-wood formation relationships with specific models, taking into account the climatic parameters that could affect each step of wood formation. A longer time series of wood formation would be necessary for this purpose.

\section{CONCLUSIONS}

4. ZAKLJUČCI

The expansion of first formed earlywood vessels, the onset of cell wall development and lignification that first occurs in vessels and in tissues around them, the occurrence of the first latewood vessels and end of lignification of terminal xylem cells are crucial phases of wood formation in Castanea sativa. They helped us to link the dynamics of wood formation and its effect on wood structure. The variation in dynamics between the two years, 2008 and 2009, was generally smaller than the variation among the 10 study trees. Wood formation on average lasted about six months in both studied years and average tree ring widths were above $3 \mathrm{~mm}$. Earlywood on average formed about one quarter and latewood about three quarters of xylem rings in both years. The recorded differences in timing of wood formation phases did not seem to have a major impact on wood structure as characterized by tree-ring widths and earlywood/latewood percentages.

\section{ACKNOWLEDGEMENTS} ZAHVALE

The work was supported by PRAL 2003/53 of the Latium Region and by Comune del Soriano nel Cimino (Italy), LLP ERASMUS bilateral agreement between the University of Ljubljana and Tuscia University, as well as programmes P4-0015 and P4-0107 and project L7-2393 funded by the Slovenian Research Agency (Ministry of Higher Education, Science and Technology). We thank Angela Bistoni, Manuel Agrumi, Luka Krže and Matej Vovk for their help in the field and laboratory.

\section{REFERENCES}

5. LITERATURA

1. Barbaroux C.; Bréda, N., 2002. Contrasting distribution and seasonal dynamics of carbohydrate reserves in stem wood of adult ring-porous sessile oak and diffuse-porous beech trees. Tree Physiology 22: 1201-1210.

2. Ciampi, C., 1951: Evoluzione della cerchia in Castanea sativa Mill. Giornale Botanico Italiano 58 (2): 271-292, http://dx.doi.org/10.1080/11263505109431515

3. Conedera, M.; Manetti, M. C.; Guidici, F.; Amorini, E.. 2004. Distribution and economic potential of the Sweet chestnut (Castanea sativa Mill.) in Europe. Ecologia Mediterranea 30: 179-193.

4. Čufar, K.; Cherubini, M.; Gričar, J.; Prislan, P.; Spina, S.; Romagnoli, M., 2011: Xylem and phloem formation in chestnut (Castanea sativa Mill.) during the 2008 growing season. Dendrochronologia, 29: 127-134, http://dx.doi.org/10.1016/j.dendro.2011.01.006

5. Derr, W.F.; Evert, R. F., 1967: The cambium and seasonal development of the phloem in Robinia pseudoacacia. Amer. J. Bot. 54(2): 147-153, http://dx.doi.org/10.2307/2440792

6. Fonti, P.; Macchioni, N., 2003: Ring shake in chestnut: anatomical description, extent and frequency of failures. Ann. For. Sci. 60: 403-408, http://dx.doi.org/10.1051/forest:2003032

7. Fonti, P.; Solomonoff, N.; Garcia-Gonzalez, I., 2007: Earlywood vessels of Castanea sativa record temperature before their formation. New Phytol. 173, 562-570, http://dx.doi.org/10.1111/j.1469-8137.2006.01945.x

8. Gričar, J., 2010: Xylem and phloem formation in Sessile oak from Slovenia in 2007. Wood Research, 55 (4): 15 22.

9. Grünwald, C.; Ruel, K.; Schmitt, U., 2002: Differentiation of xylem cells in rolC transgenic aspen trees - a study of secondary wall development. Ann. For. Sci. 59: 679-685, http://dx.doi.org/10.1051/forest:2002056

10. Horáček, P.; Šlezingerová, J.; Gandelová, L., 2003. Analysis of cambial activity and formation of wood in Quercus robur. Journal of Forestry Science. 2003. 49, 9: 412418.

11. Kollmann F.; Cote, W., 1968: Principles of Wood Science and Technology. Vol. I: Solid Wood. Berlin, Heidelberg, New York: Springer Verlag.

12. Marion, L.; Gričar, J., Oven, P., 2007: Wood formation in urban Norway maple trees studied by the micro-coring method. Dendrochronologia 25 (2): 97-102, http://dx.doi.org/10.1016/j.dendro.2007.05.001 
13. Murakami Y., Funada, R.; Sano, Y.; Ohtani, J., 1999: The differentiation of contact cells and isolation cells in the xylem ray parenchyma of Populus maximowiczii. Ann. Bot. 84: 429-435,

http://dx.doi.org/10.1006/anbo.1999.0931

14. Nardi Berti, R., 2006: La struttura anatomica del legno ed il riconoscimento dei legnami italiani di più corrente impiego. 2. ed. CNR IVALSA.

15. Piovesan, G.; Biondi, F.; Di Filippo, A.; Alessandrini, A.; Maugeri, M., 2008: Drought-driven growth reduction in old beech (Fagus sylvatica) forests of the central Apennines, Italy. Glob. Change Biol. 14 (6): 1265-1281, http://dx.doi.org/10.1111/j.1365-2486.2008.01570.x

16. Prislan, P.; Koch, G.; Čufar, K.; Gričar, J.; Schmitt, U., 2009: Topochemical investigations of cell walls in developing xylem of beech (Fagus sylvatica L.). Holzforschung, 63 (4): 482-490, http://dx.doi.org/10.1515/HF.2009.079

17. Romagnoli, M.; Nocetti, M.; Sarlatto, M.; Evangelistella, L., 2004: Dendrochronological assessment of chestnut (Castanea sativa Mill.) for dating purposes in central Italy. Dendrochronologia 21(3): 117-130.

18. Romagnoli, M.; Nocetti, M.; Sarlatto, M., 2005: Datazione dendrocronologica di strutture lignee nei tetti in Italia centro-meridionale. In: Proceedings of the International Conference "Conservation of historic Wooden Structures". 22-27 Febbraio, Firenze: 19-24.

19. Romagnoli, M., 2007: Scienze del Legno nel territorio Tuscia tra arte archeologia e ambiente: casi di studio. Informazioni, periodico dell'Ente Provincia di Viterbo Ufficio Documentazione e Valorizzazione delle Risorse Territoriali, 36-46

20. Rossi, S.; Anfodillo, T.; Menardi, R., 2006: Trephor: a new tool for sampling microcores from tree stems, IAWA J. 27: 89-97.

21. Sass, U., 1993. Die Gefäße der Buche als ökologische Variable - Bildanalytische Erfassung, dendroklimatologische Prüfung, ökologische Bewertung. Doctoral dissertation. Hamburg, Universität Hamburg.

22. Sass-Klaassen, U.; Sabajo, C. R.; den Ouden, J., 2011: Vessel formation in relation to leaf phenology in pedunculate oak and European ash. Dendrochronologia 29: 171-175, http://dx.doi.org/10.1016/j.dendro.2011.01.002
23. Schmitt, U.; Möller, R.; Eckstein, D., 2000: Seasonal wood formation dynamics of beech (Fagus sylvatica L.) and black locust (Robinia pseudoacacia L.) as determined by the "pinning" technique. J. Appl. Bot. 74: 1016.

24. Schweingruber, F. H., 1990. Microscopic wood anatomy. Birmensdorf: Eidgenössische Anstalt für das Forstliche Versuchswesen.

25. Servizio idrografico 2009, URL: $<$ http://www.idrografico.roma.it/default.aspx $>$ (date of accession 26 July 2011).

26. Spina S.; Romagnoli M., 2010: Characterization of ring shake defect in chestnut wood in the Lazio Region (Italy), Forestry 83: 315-327, http://dx.doi.org/10.1093/forestry/cpq014

27. Suzuki, M.; Yoda, K.; Suzuki, H., 1996: Phenological comparison on the onset of vessel formation between ring-porous and diffuse-porous deciduous trees in a Japanese temperate forest. IAWA J. 17: 431-444.

28. Terashima, N., 2000: Formation and ultrastructure of lignified plant cell walls. In: New Horizons in Wood Anatomy. Eds. Kim, Y.S. Chonnam National University Press, Kwangju. pp. 169-180.

29. Wagenführ, R., 1996: Holzatlas. 4th edition. Leipzig: Fachbuchverlag.

30. Werf, van der G.W.; Sass-Klaassen, U.; Mohren, G.M.J., 2007: The impact of the 2003 summer drought on the intra-annual growth pattern of beech (Fagus sylvatica L.) and oak (Quercus robur L.) on a dry site in the Netherlands. Dendrochronologia 25: 103-112.

\section{Corresponding address:}

Prof. KATARINA ČUFAR, Ph.D.

University of Ljubljana, Biotechnical Faculty, Department of Wood Science and Technology, Rožna dolina, Cesta VIII/34, SI-1000 Ljubljana, SLOVENIA e-mail: katarina.cufar@bf.uni-lj.si 